l'animal syngénique par deux voies différentes. Après injection intraveincuse, toutes les lignées cellulaires tumorales induisent des métastases artificielles massives évidentes, principalement dans le poumon. Greffées par voic sous-cutanéc, elles ne produisent que des micrométastases pulmonaires invisibles par analyse histologique directe mais détectables par immunofluorescence à l'aide d'anticorps dirigés contre l'antigène $T$ de SV40. Ces micrométastases contiennent des cellules quiescentes logées dans le poumon. Quand elles sont retirées de ce contexte tissulaire et injectées par voic sous-cutanéc, elles récupèrent lcur pouvoir prolifératif : elles se multiplient en formant une tumcur locale qui produit à nouveau des micrométastases pulmonaires. Ces résultats démontrent que les cellules tumorales considérées ont la capacité de migrer vers le poumon et de s'y maintenir sans toutefois produire de métastases macroscopiques

\section{Summary}

Cellular immortalization : from the concept to the applications

Immortalization of rodent embryo fibroblasts by SV40 defined by an unlimited proliferative capacity in vitro is dominantly maintained by the Large $T$ antigen. This manuscript summarizes some of the data accumulated in my laboratory over the last years, aiming at defining the immortalized phenotype via the characterization of the biochemical events associated with the proliferative capacity. The potentiality of using the SV40 Large $T$ antigen for the establishment of various differentiated cell lines is also presented.

\section{Références}

1. Petit CA, Gardes MY, Fcunteun J. Immortalization of rodent embryo fibroblasts by SV40 is maintained by the $A$ gene. Virology 1983 ; 127 : 74-82.

2. Mignotte B, Larcher JC, Zheng DQ, Esnault C, Coulaud D, Feunteun J. SV40-induced cellular immortalization : phenotypic changes associated with the loss of proliferative capacity in a conditionally immortalized cell line. Oncogene $1990 ; 5: 1529-33$.

3. Jacquemin-Sablon H, Ganz L, Feunteun $\mathrm{J}$. Transfer of immortality by transfection of genomic DNA from SV40 established cell lines into ral embryo fibroblasts. Biol Cell $1990 ; 68: 227-30$

4. Pinet F, Corvol MT, Dench F, et al. Isolation of renin producing human cells by transfection with three simian virus 40 mutants. Proc Nall Acad Sci USA 1985; 82 : 8503-7.

Ce résumé présente les contributions de : CarolAnn Petit, Maryvonne Gardes, Hélène Jacquenin-Sablon, Luis Mir, Lenny Ganz, Bernard Mignotte, Duo-Q $Q_{i}$ Zheng et Angela Virone dans mon laboratoire.
5. Emami S, Mir L, Chanut P, et al. Expression of histamine and vasoactive intestinal peptide VIP receptors in immortalized rat fetal intestinal cells. Agents and Actions 1988 ; $23: 276-9$.

\title{
Immortalisation et transformation tumorale de l'épithélium gastro-intestinal chez I'homme et le rat: applications en cancérologie et dans la mucoviscidose
}

\author{
Éric Chastre, Shahin Emami, Christian Gespach
}

$\mathbf{L}$ es cancers de l'estomac et du côlon représentent une cause majeure de mortalité chez l'homme, avec l'apparition de 25000 nouvcaux cas par an pour les cancers colorectaux en France. Les tumcurs digestives résistent à la chimiothérapie et produisent souvent des métastases dans le foie et le poumon. La transformation tumorale s'intègre à une cascade d'événements coopératifs

E. Chastre, S. Emami, C. Gespach : Inserm U. 55, hôpital Saint-Antoine, 75012 Paris, France. incluant l'initiation, la promotion et la progression néoplasique. Ces étapes pcuvent être successivement franchics sous l'action d'agents génotoxiques alimentaires, de mutagènes de nature chimique ou physique (carcinogènes, radiations, radicaux libres), ou à la suite de recombinaisons de séquences virales ou rétrovirales. L'oncogenèse est généralement associée à l'amplification génique aboutissant à la transcription excessive de certains (onco)gènes, comme myc ou erbB-2, à des mutations et à des réarrangements conduisant : (1) à la suppression de l'activité d'anti-oncogènes (p53, Rb), (2) à la dérégulation d'éléments transcriptionnels : promoteurs et enhancers ; (3) à l'activation constitutive d'oncoprotéines possédant un pouvoir transformant (Ras, Src, ErbB-2, Neu). L'insertion fonctionnclle d'oncogènes par transfection cellulaire ou infection rétrovirale représente une méthode alternative à l'étude de la carcinogenèse chimique et à l'établissement de lignécs issues de cancers de l'estomac ou du côlon chez l'homme ou l'animal. Cette méthode permet une analyse séquentielle et relativement 
simplifiée de la progression néoplasique. Nous avons développé cette technique afin d'étudier la complémentarité entre des oncogènes immortalisants d'origine virale ou cellulaire ( $m y c, p 53$ mute) et les oncogènes transformants représentatifs de l'évolution tumorale dans l'estomac et le côlon : erbB-2, ras, $\operatorname{src}[1]$.

- Les lignées immortalisées SLC [2, 3] ont été établies après transfection de l'épithélium intestinal chez le fotus de rat de 19 jours par des plasmides recombinés avec la région $\mathrm{E} 1 \mathrm{~A}$ de l'adénovirus 2 (SLC-11), le grand T des virus polyome (SLC-21) et SV40 (SLC-41). Ces cellules ne sont pas tumorales chez la souris athymique et conservent certains phénotypes de l'épithélium intestinal : expression de cytokératines, villine, récepteurs VIPergiques et $\beta 1$-adrénergiques, enképhalinase. Sous l'action du mésenchyme intestinal de poulet, le clone SLC-44 est capable de se différencier en entérocytes [4].

- Les glandes gastriques et les cellules épithéliales intestinales ont été isolées chez le fotus de rat de 19 jours et le rat axénique de 4 semaines. Ce matériel a été exposé en culture aux rétrovirus SV40-6, recombinés avec le grand T de SV40 (T-SV40). Nous avons obtenu 5 lignées gastriques RGC et 3 lignées intestinales ESKI. Seule la lignée RGC-3 qui possède un caryotype normal est tumorale. Les lignées RGC-3 et ESKI-2 possèdent une morphologie épithéliale en microscopie optique et une ultrastructure indifférenciée en microscopie électronique. L'expression du gène $O C I-5$, un marqueur de l'endoderme, est observée dans les lignées RGC et ESKI. - Les cellules épithéliales intestinales isolées chez un fotus porteur de la mucoviscidose ont été électroperméabilisées et transfectées par un vecteur d'expression du T-SV40. La lignée obtenue a été désignée CFI-3 [5] et semble engagée dans le processus d'immortalisation, consécutivement à l'insertion fonctionnelle de l'oncogène viral (étude en Northern blot et en immunofluorescence). La persistance de la mutation du gène CFTR est confirmée par l'analyse du polymorphisme de de Pst 1 pour la sonde KM19. L'expression du gène CFTR est décelée dans la lignée CFI-3 après action de la transcriptase inverse sur l'ARN total et amplification de l'ADNc par la PCR utilisant des oligonucléotides capables de s'hybrider aux exons 15 et 16 du gène CFTR.

- Les cellules immortalisées SLC-44 et deux lignées tumorales du côlon humain, $\mathrm{CaCo}-2$ et HT-29, ont subi une série de transfections par l'oncogène humain Ha-ras muté et le moyen $T$ du polyome (MT-Py). L'antigène $M T$-Py est capable d'activer le produit de $s r c$, la tyrosine kinase pp60sc. Les cellules $\mathrm{CaCo}-2$ produisent des tumeurs peu évolutives chez la souris athymique et présentent une différenciation entérocytaire spontanée à confluence. Les cellules HT-29 peuvent être dirigées vers cette différenciation par le butyrate ou une privation de glucose. L'induction et l'activation du pouvoir tumoral dans les lignées SLC-44 et $\mathrm{CaCo}-2$ sont la conséquence directe de l'insertion dans le génome et de l'expression de Ha-ras muté et de $M t-P y$, analysée par Northern blot et Western blot dans les lignées SLC-44, CaCo-2 et HT-29. L'activa-

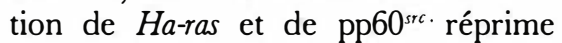
considérablement la différenciation entérocytaire et fonctionnelle de la lignée $\mathrm{CaCo}-2$, appréciée en microscopie électronique et par la mesure des activités sucrase-isomaltase et phosphatase alcaline.

Ces lignées immortalisées et transformées constituent un support nouveau et puissant d'analyse des mécanismes génétiques et moléculaires impliqués dans la prolifération des cellules épithéliales digestives, la transformation tumorale et le processus invasif des cancers gastriques et colorectaux. Le développement de vecteurs recombinés portant des oncogènes dont l'expression serait contrôlée par des promoteurs conditionnels, devrait permettre de mieux contrôler la prolifération cellulaire et la transformation tumorale, et de diriger ainsi les lignées permanentes vers la différenciation et l'étude des fonctions digestives. La lignée épithéliale CFI-3 constitue, par ailleurs, un modèle privilégié dans l'étude du dysfonctionnement de la protéine
CFTR et la dérégulation du canal chlore dans la mucoviscidose $[1,5,6]$. Elle permet d'évaluer la complémentation du gène CFTR muté par un vecteur d'expression du gène normal en vue de développer une thérapie génique in vitro. L'expression ciblée d'(onco)gènes associés à des promoteurs spécifiques de l'épithélium gastrointestinal chez les souris transgéniques [7-9] représente une stratégie complémentaire, afin d'établir les relations fonctionnelles entre l'expression du transgène, l'organogenèse fœtale et post-natale, la progression néoplasique et le (dys)fonctionnement des cellules exocrines et endocrines du tractus digestif, in vivo

\section{Remerciements}

Nous remercions le ministère de la Recherche et de l'Enseignement supérieur (contrat $n^{\circ} 87 \mathrm{~T}$ 0424, 1988-1989), l'Association française de lutte contre la mucoviscidose (1990) et la Ligue contre le cancer (1990) pour leur aide à la réalisation de ces travaux.

\section{Summary}

Immortalization and neoplastic transformation of the human and rat gastrointestinal epithelia : applications in carcino-genesis and cystic fibrosis

The goal of these studies was to analyze the genetic and molecular mechanisms involved in the neoplastic transformation of the gastrointestinal mucosa, using sequential insertions of oncogenic sequences in normal (E1A of adenovirus 2, large $\mathrm{T}$ of polyoma and SV40), and immortalized epithelial cells originating from the digestive tract. A series of immortalized cell lines has been established after transfection or retroviral infection of rat gastric (RGC cell lines) and intes- 
tinal epithelial cells (SLC and ESKI cell lines). The functional insertion of the activated human Ha-ras oncogene or polyoma middle $\mathrm{T}$, an activator of the $\mathrm{pp} 60^{\text {src }}$ tyrosine kinase, is associated with the induction and activation of the cancer growth of SLC-44 cells and human colonic cells $\mathrm{CaCo}-2$ in the nude mice. These immortalized and transformed cell lines may thus be useful for studying many aspects of gastric and colonic cancers, including proliferation, differentiation, metastasis and the MDR phenotype. The development of similar immortal cell lines in cystic fibrosis, such as the intestinal CFI-3 cells [5], may also improve our understanding of the biochemical alterations related to genetic defects in man.

\section{Références}

1. Chastre E, Emami S, Gespach C. Expression of membrane receptors and (proto)oncogenes during the ontogenic development and neoplastic transformation of the intestinal mucosa. Life Sci 1989 ; 44 : 1721-42.

2. Emami S, Mir L, Gespach C, Rosselin G. Transfection of fetal rat intestinal epithelial cells by viral oncogenes : establishment and characterization of the E1A-immortalized SLC-11 cell line. Proc Natl Acad Sci USA 1989 ; 86 : 3194-8.

3. Lévy P, Emami S, Cherqui G, Chastre E, Gespach C, Picard J. Altered expression of proteoglycans in E1A-immortalized rat fetal intestinal epithelial cells in culture. Cancer Res $1990 ; 50$; 6716-22.

4. Emami S, Chastre E, Nizard S, et al. Immortalization and neoplastic transformation of fetal rat intestinal epithelial cells : morphological and cytogenetic analysis, (proto)oncogene expression and effect of $\gamma$-interferon on cell growth. Digestion $1990 ; 46: 74-91$.
5. Chastre E, Lemnouar M, Paul A, et al. Oncogene-mediated immortalization of CF epithelial cells isolated from the intestine and trachea. Pediatric Pulmonology 1990 ; suppl. 5 : 198.

6. Chastre E, Bawab W, Faure C, et al. Vasoactive intestinal peptide and its receptors in fetuses with cystic fibrosis. Am J Physiol $1989 ; 257$ : G561-9.

7. Cartier N, Lepetit N, Tulliez M, et al. Des cancers dépendant du régime chez les souris transgéniques : les surprises d'un promoteur hépatique. Journées Curie sur les oncogènes et la génétique du cancer, 1-2 février 1990, Orly, France, abstract $n^{\circ} 102$

8. Hauft S, Sweetser D, Rotwein P, et al. A transgenic mouse model that is useful for analyzing cellular and geographic differentiation of the intestine during fetal development. $J$ Biol Chem 1989 ; 264 : 8419-29.

9. Maunoury R, Robine S, Pringault E, et al. Villin expression in the visceral endoderm and in the gut anlage during early mouse embryogenesis. EMBO J 1988 ; 7 : 3321-9.

\title{
Characterization of human skin keratinocytes immortalized with SV40, HPV, or spontaneously
}

\author{
Petra Boukamp, Dirk Breitkreutz, Pascal Tomakidi, Norbert E. Fusenig
}

D ue to the impressive development in cell culture methodology cell lines could be established from nearly all tissues. However, there exist fewer cell lines of human than of rodent origin. This in as much is remarkable as, for example, normal human keratinocytes are much more easy to culture than normal rodent cells (they can be passaged and thereby increased in number several fold). Nevertheless they have been found to be largely resistant to transformation in vitro using either chemical or physi-

P. Boukamp, D. Breitkreutz, P. Tomakidi, N.E. Fusenig: German Cancer Research Center, IM Neuenheimerfeld 280, Heidelberg, Gennany.

$m / s n^{\circ} 4$ vol. 7, aunl 91 cal agents [1-4]. The basis for the discrepancy in transformation sensitivity is still unclear. Explanations have been postulated including interspecies differences such as natural life span, degree of inbreeding, or different genetic stability $[2,5]$.

The first agent described leading to immortalization of human keratinocytes was simian virus 40 (SV40) [6]. This potent DNA tumor virus induced a high number of cytogenetic aberrations [7] which most probably were causally related to the escape from senescence. Similar to SV40, other DNA tumor viruses - human papilloma virus 16 and 18 (HPV) have also proven to immortalize human keratinocytes reproducibly.
Thus, a number of cell lines could be established in the meantime in several laboratories using both virus types $[8,9]$.

A third possibility to establish cell lines, but obviouly a very rare event, is spontaneous immortalization, i.e. escape from senescence without addition of any known transforming agent. To date there exist only two epidermal keratinocyte lines, one derived from a culture of foreskin keratinocytes (NM1 [10]) while the other, HaCaT, originated from trunk skin [11]. The actual cause of transformation is still elusive. However, there are indications that elevated temperature (one of the conditions of the initial culture phase of the $\mathrm{HaCaT}$ 